\title{
Diallel Analysis of In Vitro Culture Traits in the Genus Lycopersicon
}

\author{
Guillermo Pratta ${ }^{1}$ \\ Consejo Nacional de Investigaciones Científicas y Técnicas
}

\author{
Lilians N. Cánepa ${ }^{2}$ \\ Postgraduate student in Plant Genetics
}

\section{Roxana Zorzoli and Liliana A. Picardi \\ Consejo de Investigaciones de la Universidad Nacional de Rosario, Cátedra de Genética, Facultad de Ciencias Agrarias, Universidad Nacional de Rosario, CC 14 S2125ZAA Zavalla, Argentina}

Additional index words. tomato, wild germplasm, callus production, shoot formation, quantitative traits

\begin{abstract}
Estimates of genetic variability for in vitro culture traits among the genus Lycopersicon and evaluation of the gene effects involved in callus production and shoot formation were achieved. Five parents including wild and cultivated tomato genotypes and their nonreciprocal 10 possible hybrid combinations were assayed. The callus percentage $(C=$ number of cultures that only produced callus $\times 100$ / total number of cultures), the regeneration percentage $(R=$ number of cultures that differentiated into shoots or primordia $\times 100$ / total number of cultures) and the productivity rate $(P R=$ total number of shoots $/$ total number of cultures) of each genotype were calculated 45 days after culture initiation. Diallel analysis revealed genetic variability for in vitro culture response. Wild genotypes contributed to a reduction in callus production and an increase in shoot formation while the cultivated genotypes either had an opposite effect or did not modify the expression of culture traits. Hybrids had the lowest callus production and highest shoot formation percentage. Additive gene effects were mainly involved in the expression of $C$ and $R$, while both additive and nonadditive gene effects were involved in expression of PR.
\end{abstract}

Dedifferentiation of tomato (Lycopersicon esculentum Mill.) leaf explants into callus, followed or not by shoot formation is dependent on genotype, culture medium and physiological stage of the donor plants (Hamada, 1998; Zorzoli et al., 1993). Intra and interspecific variability for callus proliferation and shoot regeneration has been widely reported in the genus Lycopersicon, and different experiments demonstrated that cultivated genotypes had a lesser shoot formation than their wild relatives (Pratta et al., 1997; Tal et al., 1977). Consequently, wild species of Lycopersicon could be a valuable germplasm to enhance tomato shoot formation by introgressing specific genes (Rick and Yoder, 1995).

Although genetic control of in vitro culture traits was investigated in various crops (Kuroda et al., 1998; Nestares et al., 1998; Nesticky et al., 1983) there is not enough information regarding quantitative studies on in vitro competence of Lycopersicon species (Faria and Illg, 1996; Frankerberger et al., 1981). Analytical

Received for publication 10 Sept. 2001.Accepted for publication 14 May 2002. This work is part of the Thesis Dissertation of L.N.C. for a Magister degree in Plant Genetics. We thank Seminis Seed Co. for partially financing the publication costs.

${ }^{1}$ To whom reprint requests should be addressed. E-mail: gpratta@fcagr.unr.edu.ar

${ }^{2}$ Present address: Cátedra de Botánica, Facultad de Recursos Naturales, Universidad Nacional de Formosa, Avenida Gobernador Gutniski, Campus Universitario, 3200 Formosa, Argentina methods of quantitative genetics are powerful tools to measure genetic variation and gene effects involved in a metric trait, assuming the hypothesis that a polygene system underlies the trait (Griffing, 1956).

The goal of this research is to estimate the genetic contribution of wild and cultivated tomato genotypes to in vitro culture traits. The current study was designed to evaluate the existence of genetic variability and gene effects involved in both in vitro callus production and shoot formation, since partition of genetic variation into its additive and nonadditive components is an important step in determining the most adequate breeding strategy for the traits. The degree of heterosis and both general and specific combining ability were evaluated.

\section{Materials and Methods}

Plant material. Five homozygous genotypes, cultivar 'Caimanta', an inbred line homozygous for the mutant allele nor ('A') and an inbred line homozygous for the mutant allele $\operatorname{rin}($ ' $\mathrm{B}$ ') of the cultivated tomato, and the wild accessions LA 1385 of L. esculentum var. cerasiforme and LA722 of L. pimpinellifolium, were crossed in a nonreciprocal diallel combination (Eberhart and Gardner, 1966). Seeds of the five parents and 10 hybrids were sown in seeedling trays under greenhouse conditions during Sept. 1999 at the field station "José F. Villarino" Argentina, $33^{\circ} \mathrm{S}$ and $61^{\circ} \mathrm{W}$ ). Four plants per (Facultad de Ciencias Agrarias UNR, Zavalla, genotype were selected for in vitro experiments $40 \mathrm{~d}$ after sowing.

In vitro culture. Explants were obtained from the third completely expanded leaf below the apex. Leaflets were sectioned in 6-10 pieces of $5 \mathrm{~mm}$ diameter, disinfected with $96 \%$ ethanol for $5 \mathrm{~s}$ and $4 \%$ sodium hypochlorite for 4 minutes. Explants were rinsed three times in distilled water and cultured abaxial side down in 48-mL tubes containing $10.5 \mathrm{~mL}$ of the Murashige and Skoog (1962) salts and vitamins supplemented with $30 \mathrm{~g} \cdot \mathrm{L}^{-1}$ sucrose, $1 \mu \mathrm{M}$ indol-3-acetic acid and $10 \mu \mathrm{M} \mathrm{N}^{6}$-benzylaminopurine. The $\mathrm{pH}$ of the culture medium was adjusted to 5.8 before the addition of $9 \mathrm{~g} \cdot \mathrm{L}^{-1}$ purified agar (Sigma). Cultures $(n=463)$ were incubated in an acclimatized room at $25 \pm 2{ }^{\circ} \mathrm{C}$ and a 16-h photoperiod of 1500 lux according to a completely randomized design, in which plants $(\mathrm{N}=60)$ were the replications.

Data analysis. The callus percentage $(\mathrm{C}=$ number of cultures that only produced callus $\times 100 /$ total number of cultures), regeneration percentage $(\mathrm{R}=$ number of cultures that differentiated into shoots $\times 100 /$ total number of cultures), and productivity rate $(\mathrm{PR}=$ total number of shoots / total number of cultures) were evaluated for each genotype $45 \mathrm{~d}$ after culture initiation. Hence shoot formation was assessed in two different ways: $\mathrm{R}$ for measuring the frequency of regeneration and PR for measuring the amount of regeneration. The normal distribution of each variable was tested according to Shapiro and Wilk (1965). Mean values of $C, R$, and PR were classified by Duncan's multiple range test.

The diallel analysis for the three variables was performed following the Eberhart and Gardner (1966) fixed model:

$$
\begin{aligned}
\mathrm{Y}_{\mathrm{ii}},= & \mu+1 / 2\left(\mathrm{p}_{\mathrm{i}}+\mathrm{p}_{\mathrm{i}^{\prime}}\right)+ \\
& \theta\left(\mathrm{H}_{\mathrm{m}}+\mathrm{h}_{\mathrm{i}}+\mathrm{h}_{\mathrm{i}},+\mathrm{s}_{\mathrm{ii}}\right)+\mathrm{e}_{\mathrm{ii}{ }^{\prime} \mathrm{j}}
\end{aligned}
$$

where $\mu=$ the parents' mean, $\mathrm{p}_{\mathrm{i}}=$ the parent effect, $\theta=0$ for parents and 1 for hybrids, $\mathrm{H}_{\mathrm{m}}=$ the average heterosis, $\mathrm{h}_{\mathrm{i}}$ is the parent heterosis, $\mathrm{s}_{\mathrm{ii}}$, $=$ the specific heterosis, and $\mathrm{e}_{\mathrm{ii}{ }^{\prime} \mathrm{j}}=$ the error term. The average heterosis, the parent heterosis and the specific heterosis are the components of the mid-parent heterosis $(\mathrm{H})$, which is computed as $\mathrm{H}=\mathrm{H}_{\mathrm{m}}+\mathrm{h}_{\mathrm{i}}+\mathrm{h}_{\mathrm{i}}$, $+\mathrm{s}_{\mathrm{ii}}$ ' for a particular cross. The general combining ability of each parent $\left(\mathrm{g}_{\mathrm{i}}\right)$ was obtained by $\mathrm{g}_{\mathrm{i}}=$ $1 / 2 p_{i}+h_{i}$, being this value equivalent to that from method Four of Griffing (1956).

\section{Results and Discussion}

In vitro callus proliferation and shoot formation were observed from explants of all genotypes. Shapiro-Wilk test (Shapiro and Wilk, 1965) revealed that $C, R$, and PR were normally distributed $(\mathrm{W}=0.92, P<0.05$ for $\mathrm{C} ; \mathrm{W}=0.91, P<0.01$ for $\mathrm{R} ; \mathrm{W}=0.80, P<$ 0.01 for $P R)$. Differences among the genotypes were detected for C, R and PR (Table 1).

The existence of genetic variability for callus production and shoot formation, was detected among a set of homozygous and hybrid Lycopersicon genotypes (Table 2). Hybrids had higher mean values of regeneration percentage and productivity rate than the parents with 
Table 1. Analysis of variance of the callus percentage, the regeneration percentage, and the productivity rate according to the fixed model of Eberhart and Gardner (1966) for complete diallel crosses without reciprocals.

\begin{tabular}{|c|c|c|c|c|c|c|c|c|c|c|}
\hline \multirow[b]{2}{*}{ Source } & \multicolumn{4}{|c|}{ Callus (\%) } & \multicolumn{3}{|c|}{ Regeneration (\%) } & \multicolumn{3}{|c|}{ Productivity rate } \\
\hline & $\mathrm{df}^{2}$ & $\mathrm{SS}^{\mathrm{y}}$ & $\mathrm{MS}^{\mathrm{x}}$ & $\mathrm{F}$ value & SS & MS & F value & SS & MS & F value \\
\hline Genotypes & 14 & 2.5357 & 0.1811 & $2.39^{*}$ & 2.4271 & 0.1734 & $2.18^{*}$ & 132.30 & 9.45 & $3.57^{* *}$ \\
\hline Parents & 4 & 0.8819 & 0.2205 & $2.91^{*}$ & 0.4837 & 0.1209 & $1.52^{\mathrm{Ns}}$ & 18.83 & 4.71 & $1.78^{\mathrm{Ns}}$ \\
\hline Heterosis & 10 & 1.6538 & 0.1654 & $2.18^{*}$ & 1.9434 & 0.1943 & $2.45^{*}$ & 113.47 & 11.35 & $4.28^{* *}$ \\
\hline Average heterosis & 1 & 0.1491 & 0.1491 & $1.96^{\mathrm{Ns}}$ & 0.3575 & 0.3575 & $4.50^{*}$ & 8.67 & 8.67 & $3.27^{\mathrm{Ns}}$ \\
\hline Parent heterosis & 4 & 0.6941 & 0.1735 & $2.29^{\mathrm{Ns}}$ & 0.7673 & 0.1918 & $2.42^{\mathrm{Ns}}$ & 43.99 & 11.00 & $4.15^{* *}$ \\
\hline Specific heterosis & 5 & 0.8106 & 0.1621 & $2.14^{\mathrm{Ns}}$ & 0.8186 & 0.1637 & $2.06^{\mathrm{NS}}$ & 60.81 & 12.16 & $4.59^{* * *}$ \\
\hline Error & 45 & 3.4162 & 0.0759 & --- & 3.5732 & 0.0794 & --- & 119.08 & 2.65 & --- \\
\hline Total & 59 & $5.9519^{x}$ & --- & --- & 6.003 & --- & --- & 251.38 & --- & --- \\
\hline General combining ability $^{\mathrm{w}}$ & 4 & 1.5079 & 0.3770 & $4.97^{* *}$ & 1.0965 & 0.2741 & $3.45^{*}$ & 51.05 & 12.76 & $4.82^{* *}$ \\
\hline
\end{tabular}

${ }^{2}$ Degrees of freedom.

${ }^{y}$ Sum of squares

${ }^{x}$ Mean squares.

${ }^{\mathrm{w}}$ According to method 4 of Griffing (1956).

ns, *, ** Nonsignificant or significant at $P<0.05$ or $P<0.01$, respectively.

Table 2. Means and analysis of variance of the callus percentage, the regeneration percentage, and the productivity rate of tomato genotypes.

\begin{tabular}{|c|c|c|c|c|}
\hline \multirow[b]{2}{*}{ Genotypes } & \multicolumn{4}{|c|}{ Variables $^{y}$} \\
\hline & $\overline{n^{2}}$ & $\mathrm{C}$ & $\mathrm{R}$ & PR \\
\hline Caimanta & 33 & $84.5 \mathrm{a}$ & $15.5 \mathrm{~cd}$ & $0.4 \mathrm{c}$ \\
\hline A & 37 & $89.5 \mathrm{a}$ & $7.5 \mathrm{~d}$ & $0.2 \mathrm{c}$ \\
\hline $\mathrm{B}$ & 30 & $33.3 \mathrm{~b}-\mathrm{d}$ & $46.5 \mathrm{a}-\mathrm{d}$ & $1.4 \mathrm{c}$ \\
\hline LA1385 & 38 & $51.3 \mathrm{a}-\mathrm{d}$ & $40.3 \mathrm{a}-\mathrm{d}$ & $2.9 \mathrm{bc}$ \\
\hline LA722 & 31 & $58.8 \mathrm{a}-\mathrm{d}$ & $40.8 \mathrm{a}-\mathrm{d}$ & $1.3 \mathrm{c}$ \\
\hline $\mathrm{F}_{1}($ Caimanta $\times \mathrm{A})$ & 28 & $74.5 \mathrm{ab}$ & $25.5 \mathrm{~cd}$ & $0.6 \mathrm{c}$ \\
\hline $\mathrm{F}_{1}(\mathrm{~B} \times$ Caimanta $)$ & 28 & $56.0 \mathrm{a}-\mathrm{d}$ & $41.0 \mathrm{a}-\mathrm{d}$ & $1.1 \mathrm{c}$ \\
\hline $\mathrm{F}_{1}(\mathrm{~B} \times \mathrm{A})$ & 32 & $76.8 \mathrm{ab}$ & $19.8 \mathrm{~cd}$ & $0.5 \mathrm{c}$ \\
\hline $\mathrm{F}_{1}$ (Caimanta $x$ LA1385) & 36 & $20.0 \mathrm{~d}$ & $80.0 \mathrm{a}$ & $4.3 \mathrm{ab}$ \\
\hline $\mathrm{F}_{1}(\mathrm{~A} \times \mathrm{LA} 1385)$ & 29 & $67.8 \mathrm{a}-\mathrm{c}$ & $32.3 \mathrm{~b}-\mathrm{d}$ & $1.3 \mathrm{c}$ \\
\hline $\mathrm{F}_{1}(\mathrm{~B} \times \mathrm{LA} 1385)$ & 24 & $55.0 \mathrm{a}-\mathrm{d}$ & $45.0 \mathrm{a}-\mathrm{d}$ & $1.7 \mathrm{c}$ \\
\hline $\mathrm{F}_{1}$ (Caimanta $x$ LA722) & 39 & $69.8 \mathrm{abc}$ & $30.3 \mathrm{~b}-\mathrm{d}$ & $1.1 \mathrm{c}$ \\
\hline $\mathrm{F}_{1}(\mathrm{~A} \times \mathrm{LA} 722)$ & 28 & $48.0 \mathrm{a}-\mathrm{d}$ & $52.0 \mathrm{a}-\mathrm{d}$ & $1.3 \mathrm{c}$ \\
\hline $\mathrm{F}_{1}(\mathrm{~B} \times \mathrm{LA} 722)$ & 25 & $23.5 \mathrm{~cd}$ & $76.5 \mathrm{ab}$ & $5.6 \mathrm{a}$ \\
\hline $\mathrm{F}_{1}$ (LA1385 x LA722) & 25 & $37.5 \mathrm{~b}-\mathrm{cd}$ & $62.5 \mathrm{a}-\mathrm{c}$ & $2.9 \mathrm{bc}$ \\
\hline
\end{tabular}

${ }^{\mathrm{z}} \mathrm{n}=$ number of explants per genotype

'Mean separation in columns according to Duncan's multiple range test $(P<0.05)$.

performance being more evident in crosses involving at least one wild parent. However, the $\mathrm{F}_{1}$ ('B' $\mathrm{x}$ 'Caimanta') also had relatively high values of $R$ and PR (Table 2). Ranges of variation within hybrids (from 20.0 to 76.8 ) and within parents (from 33.3 to 89.5 ) were quite similar for callus production, with the hybrids having the lowest values. This preliminary result suggested that additive effects were mostly involved in the expression of this trait. However, for shoot formation the range of variation within hybrids (from 19.8 to 80.0 for $\mathrm{R}$ and 0.5 to 5.6 for $\mathrm{PR}$ ) was larger than within parents (from 7.5 to 46.5 for R and 0.2 to 2.9 for PR; Table 2). The wider genetic variation showed by the hybrids indicated that nonadditive effects were involved in this trait.

Estimates of parent effects $\left(\mathrm{p}_{\mathrm{i}}\right)$, parent heterosis $\left(\mathrm{h}_{\mathrm{i}}\right)$ and general combining ability $\left(\mathrm{g}_{\mathrm{i}}\right)$ are in Table 3. For C, the parents' mean $(\mu)$ was 63.5 and the average heterosis $\left(\mathrm{H}_{\mathrm{m}}\right)$ was -10.6 (the hybrids' mean was 52.9 ). For $\mathrm{R}, \mu=30.1$ and $\mathrm{H}_{\mathrm{m}}=16.4$ and for PR, $\mu=$ 1.0 and $\mathrm{H}_{\mathrm{m}}=1.0$ (the hybrids' means were 46.5 and 2.0, respectively). Estimates of the specific combining ability $\left(\mathrm{s}_{\mathrm{iii}}\right)$ and the midparent heterosis $(\mathrm{H})$ are in Table 4. Mid-parent heterosis was significant for all in vitro traits (Table 1). The partition of the heterosis effects showed that none of the components was significant for the callus percentage, the average heterosis was significant just for the regeneration percentage, and the parent and specific heterosis were highly significant only for the productivity rate. According to these results, the diallel analyses confirmed the former proposition regarding the genetic effects involved in the determination of the traits.

Shoot formation was always indirect, i.e. explants dedifferentiated into callus before regenerating. Most explants callused but only a few genotypes produced shoots, making the callus and regeneration percentage almost complementary. However, some 'B' explants failed to produce callus and shoots (Table 2). Pratta et al. (1997) concluded that dedifferentiation, e.g. callus production, appeared to be a common fact among Lycopersicon genotypes whereas shoot formation was restricted to certain genotypes. Hence, negative heterosis of callus percentage could be assigned to the highest shoot formation of the hybrids.

Christianson and Warnick (1983, 1988) divided the process of organogenesis into three phases, based on the temporal requirements of explants: acquisition of competence, determination for producing an organ, and development of that organ. As measured in this experiment, the regeneration percentage becomes an assorting assessment of shoot formation, so that genotypes could be classified into "competent shoot formers" and "incompetent shoot formers". This variable would assess biological events related to the first and second phases of organogenesis (Christianson, 1987). The significant average heterosis detected for regeneration suggests that the parents carry genes that diminish the value of the trait. Hence, it was expected that high frequency of shoot formation is restored in the crosses. This fact was already suggested by Tal et al. (1977), who also included wild species in their experiment, and justifies the non significant parent and specific heterosis found in the present study for the regeneration percentage. High frequency shoot formation would be inherent to the heterozygous conditions per se and common to all hybrid combinations, especially when wild tomato species are included as the hybrids' parents. It would be possible that hybrid performance is supported by an increase in their competence and determination for shoot formation due to gene complementation taking place in the heterozygous genotypes.

The productivity rate represents a quantifying assessment of shoot formation. Since it measures the magnitude of organ development, it would asses biological events related to the third phase of organogenesis (Christianson, 1987). For this variable, the parents' mean was not different than the hybrids' mean, as it was shown by the lack of statistical significance for average heterosis (Table 1). Crosses of certain parents showed distinctive performances, such as those involving ' $\mathrm{A}$ ' with low productivity or LA722 with high productivity. This performance was validated by the significant parent heterosis (Table 1). Specific heterosis was also significant for productivity rate. The two hybrids with the highest values, $F_{1}$ ('Caimanta' $x$ LA1385) and $F_{1}$ ('B'xLA722), also had greater specific heterosis. The specific heterosis is the same as specific combining ability of Griffing (1956) and measures nonadditive gene effects. In fact dominance and over-dominance influenced the magnitude of shoot formation.

General combining ability was significant for the regeneration percentage and highly significant for the callus percentage and productivity rate (Table 1). This measurement is the average performance of a parent in hybrid combinations, and is generally accepted as an estimation of additive gene effects (Griffing, 
Table 3. Estimates of the parent effect $\left(\mathrm{p}_{\mathrm{i}}\right)$, parent heterosis $\left(\mathrm{h}_{\mathrm{i}}\right)$ and general combining ability $\left(\mathrm{g}_{\mathrm{i}}\right)$ of the callus percentage $(\mathrm{C})$, the regeneration percentage $(\mathrm{R})$, and the productivity rate $(\mathrm{PR})$ according to the fixed model of Eberhart and Gardner (1966)

\begin{tabular}{|c|c|c|c|c|c|c|c|c|c|}
\hline \multirow[b]{3}{*}{ Genotypes } & \multicolumn{9}{|c|}{ Variables } \\
\hline & \multicolumn{3}{|c|}{$\mathrm{C}$} & \multicolumn{3}{|c|}{$\mathrm{R}$} & \multicolumn{3}{|c|}{ PR } \\
\hline & $\mathrm{p}_{\mathrm{i}}$ & $\mathrm{h}_{\mathrm{i}}$ & $\mathrm{g}_{\mathrm{i}}$ & $\mathrm{p}_{\mathrm{i}}$ & $\mathrm{h}_{\mathrm{i}}$ & $\mathrm{g}_{\mathrm{i}}$ & $\mathrm{p}_{\mathrm{i}}$ & $\mathrm{h}_{\mathrm{i}}$ & $\mathrm{g}_{\mathrm{i}}$ \\
\hline Caimanta & 21.0 & -7.6 & 2.9 & -14.6 & 4.3 & -3.0 & -0.8 & 0.1 & -0.3 \\
\hline A & 26.1 & 5.5 & 18.5 & -22.6 & -7.5 & -18.8 & -1.1 & -1.0 & -1.5 \\
\hline B & -30.2 & 15.0 & -0.1 & 16.4 & -9.4 & -1.2 & 0.1 & 0.2 & 0.2 \\
\hline LA1385 & -12.2 & -4.3 & -10.4 & 10.2 & 6.2 & 11.3 & 1.7 & -0.2 & 0.7 \\
\hline LA722 & -4.7 & -8.6 & -10.9 & 10.7 & 6.5 & 11.8 & 0.1 & 0.9 & 0.9 \\
\hline
\end{tabular}

Table 4. Estimates of the specific heterosis $\left(\mathrm{s}_{\mathrm{ii}}\right.$ ) and mid-parent heterosis $(\mathrm{H})$ of the callus percentage $(\mathrm{C})$, the regeneration percentage $(\mathrm{R})$, and the productivity rate $(\mathrm{PR})$ according to the fixed model of Eberhart and Gardner (1966)

\begin{tabular}{|c|c|c|c|c|c|c|}
\hline \multirow[b]{3}{*}{ Genotypes } & \multicolumn{6}{|c|}{ Variables } \\
\hline & \multicolumn{2}{|c|}{$\mathrm{C}$} & \multicolumn{2}{|c|}{$\mathrm{R}$} & \multicolumn{2}{|c|}{ PR } \\
\hline & $\mathrm{S}_{\mathrm{ii}}$ & $\mathrm{H}$ & $\mathrm{S}_{\mathrm{ii}}$ & $\mathrm{H}$ & $\mathrm{s}_{\mathrm{ii}}$ & $\mathrm{H}$ \\
\hline$\overline{\mathrm{F}_{1}(\text { Caimanta } \times \mathrm{A})}$ & 0.2 & -12.5 & 0.9 & 14.1 & 0.4 & 0.3 \\
\hline $\mathrm{F}_{1}(\mathrm{~B} \times$ Caimanta $)$ & 0.3 & -2.9 & -1.2 & 10.1 & -0.8 & 0.2 \\
\hline $\mathrm{F}_{1}(\mathrm{~B} \times \mathrm{A})$ & 5.5 & 15.4 & -6.7 & -7.2 & -0.3 & -0.3 \\
\hline $\mathrm{F}_{1}$ (Caimanta $\mathrm{x}$ LA1385) & -25.4 & -47.9 & 25.3 & 52.2 & 1.9 & 2.6 \\
\hline $\mathrm{F}_{1}(\mathrm{~A} \times \mathrm{LA} 1385)$ & 6.8 & -2.6 & -6.7 & 8.7 & 0.1 & -0.3 \\
\hline $\mathrm{F}_{1}(\mathrm{~B} \times \mathrm{LA} 1385)$ & 12.6 & 12.7 & -11.5 & 1.7 & -1.3 & -0.5 \\
\hline $\mathrm{F}_{1}$ (Caimanta $x$ LA722) & 24.9 & -1.9 & -25.0 & 2.2 & -1.5 & 0.3 \\
\hline $\mathrm{F}_{1}(\mathrm{~A} \times \mathrm{LA} 722)$ & -12.5 & -26.2 & 12.5 & 27.9 & -0.2 & 0.5 \\
\hline $\mathrm{F}_{1}(\mathrm{~B} \times \mathrm{LA} 722)$ & -18.4 & -22.6 & 19.5 & 33.0 & 2.4 & 4.3 \\
\hline$\underline{F}_{1}(\mathrm{LA} 1385 \times$ LA722) & 6.0 & -17.5 & -7.0 & 22.1 & -0.7 & 0.8 \\
\hline
\end{tabular}

1956). Although this fact would disagree with the significant heterosis found for the three variables, nonadditive gene effects also appear to account for general combining ability according to the partition proposed by Eberhart and Gardner (1966). The nonadditive effects would be mainly due to the parent heterosis component (see the respective formulae in Materials and Methods section). Frankerberger et al. (1981) reported the absence of heterosis effects and a significant general combining ability for shoot-forming capacity in a diallel cross among selected tomato genotypes, but in their experiments wild germplasm was not included. In the present study, wild genotypes LA1385 and LA722 had negative values of general combining ability for callus percentage, and positive values for regeneration percentage and productivity rate. Hence, these parents increased not only the frequency of shoot formation but also its magnitude. Cultivated genotypes 'Caimanta' and 'A' had an opposite performance, reducing the morphogenetic response. Values of general combining ability of ' $\mathrm{B}$ ' were very near to zero, so that it did not have a noticeable effect in modifying the in vitro culture response.

The quantitative approach for studying callus production and shoot formation in $L y$ copersicon detected the existence of genetic variability for these in vitro culture traits. Mainly additive gene effects underlie callus production and both additive and nonadditive gene effects underlie shoot formation. Heterosis was a significant genetic component for determining in vitro culture competence. In consequence, a small response to artificial selection would be obtained from this set of genotypes because of the minor additive effect underlying tomato shoot formation. If an increase in this trait is desired, a breeding strategy involving crosses among wild and cultivated genotypes should be applied in order to exploit large heterosis effects.

\section{Literature Cited}

Christianson, M.L. 1987. Causal events in morphogenesis, p. 45-55. In C.E. Green et al. (eds.). Plant tissue and cell culture. Alan R. Liss, New York.

Christianson, M.L. and D.A. Warnick. 1983. Competence and determination in the process of in vitro organogenesis. Dev. Biol. 95:288-293.

Christianson, M.L. and D.A. Warnick. 1988. Organogenesis in vitro as a developmental process. HortScience 23:515-519.

Eberhart, S.A. and C.O. Gardner. 1966. A general model for genetic effects. Biometrics 20: 864-881.

Faria, R.T. and R.D. Illg. 1996. Inheritance of in vitro plant regeneration ability in the tomato. Braz. J. Genet. 19:113-116.

Frankerberger, E.A., P.M. Hasegawa, and E.C. Tigchelaar. 1981. Diallel analysis of shoot-forming capacity among selected tomato genotypes. Z. Pflanzenphysiol. 102:233-242.

Griffing, B. 1956. Concept of general and specific combining ability in relation to diallel crossing systems. Austral. J. Biol. Sci. 9:463-493.

Hamada, A.M. 1998. Genotypic differences and alterations of protein patterns of tomato plants under copper stress. Biol. Plant. 41:555-564.

Kuroda, S., H. Kato, and R. Ikeda. 1998. Heterosis and combining ability for callus growth rate in rice. Crop Sci. 38:933-936.

Murashige, T. and F. Skoog. 1962. Arevised medium for rapid growth: A bioassay with tobacco tissue cultures. Physiol. Plant. 15:473-497.

Nestares, G., R. Zorzoli, L.A. Mroginski, and L.A. Picardi. 1998. Cytoplasm effects on the regeneration ability of sunflower. Plant Breeding 117:188-190.

Nesticky, M., F.J. Novak, A. Piovarci, and M. Dolezelová. 1983. Genetic analysis of callus growth of maize (Zea mays L.) in vitro. Z. Pflanzenzücht. 91:322-328.

Pratta, G., Zorzoli, R. and Picardi, L.A. 1997. Intra and interspecific variability of in vitro culture response in Lycopersicon (tomatoes). Braz. J. Genet. 20:75-78

Rick C.M. and J.I. Yoder. 1995. Classical and molecular genetics of tomato: Highlights and perspectives. Ann. Rev. Genet. 1988:281-300.

Shapiro, S.S. and M.B. Wilk. 1965. An analysis of variance test for normality (complete samples). Biometrika 52:591-611.

Tal, M., K. Dehan, and H. Heikin. 1977. Morphogenetic potential of cultural leaf sections of cultivated and wild species of tomato. Ann. Bot. 41:937-941.

Zorzoli, R., M.S. Bueno, and L.A. y Picardi. 1993. Regeneración in vitro a partir de anteras y folíolos en genotipos de tomate. Horticultura Argentina 8-12:1-7. 